\title{
RESPON PESANTREN TERHADAP PENERAPAN PROTOKOL KESEHATAN DI TENGAH PANDEMI COVID-19 (STUDI KASUS TERHADAP TIGA PESANTREN DI SUMATRA SELATAN)
}

\author{
Nugroho ${ }^{\mathrm{a}, 1, *}$, Zaki Faddad Syarif Zain ${ }^{\mathrm{b}, 2}$, Arpah Nurhayat ${ }^{\mathrm{c}, 3}$ \\ ${ }^{a}$ UIN Raden Fatah, Palembang, 30126, Indonesia \\ ${ }^{b}$ UIN Raden Fatah, Palembang, 30126, Indonesia \\ ${ }^{c}$ UIN Raden Fatah, Palembang, 30126, Indonesia \\ ${ }^{1}$ nugroho_uin@radenfatah.ac.id*; ${ }^{2}$ zakifaddad_uin@radenfatah.ac.id*; ${ }^{3}$ m.arpah_uin@radenfatah.ac.id*;
}

ARTICLE INFO

Article history:

Received : 2021-11-01

Revised : 2021-11-28

Accepted : 2021-12-24

Keywords:

Islamic Boarding School

Pandemic

Health Protocol

\section{ABSTRACT}

This study was to reveal the theological response and application of health protocols in Islamic boarding schools during the COVID19 pandemic. The data were obtained through observations, observations and interviews in three Islamic boarding schools: Ittifaqiyah, Aulia Cendikia and Al Burhan, a Salaf Islamic Boarding School. Aulia Cendikia is affiliated with NU and Al Burhan with Jamaah Tabligh, while Ittifaqiyah is the largest pesantren in the province but is not affiliated with any religious movement. This study revealed that in the application of health protocols in Islamic boarding schools during the pandemic, there were two things. First, Islamic boarding schools applied rules in the form of SOPs for virus prevention strictly. This was performed by Pesantren Aulia Cendikia and Ittifaqiyah. Meanwhile, Al Burhan tent to apply loosely. It was concluded that the level of an Islamic boarding school and the school it adhered could determine the response to health protocols in the midst of the Covid-19 pandemic.

\section{ABSTRAK}

Penelitian ini bertujuan mengungkapkan respon teologis dan penerapan protokol kesehatan di lingkungan pesantren selama masa Pandemi COVID-19. Data dalam penelitian ini diperoleh melalui observasi, pengamatan dan wawancara di tiga pesantren Pesantren Ittifaqiyah dan Aulia Cendikia dan Al Burhan adalah Pesantren Salaf. Aulia Cendikia berafiliasi dengan NU dan Al Burhan dengan Jamaah Tabligh, semetnara Ittifaqiyah adalah pesantren terbesar di provinsi ini namun tidak berafiliasi dengan gerakan keagamaan manapun. Penelitian ini berkesimpulan bahwa dalam penerapan protokol kesehatan di lingkungan pesantren selama Pandemi terdapat dua hal. Pertama pesantren menerapkan aturan dalam bentuk SOP pencegahan virus secara ketat, ini dilakukan oleh Pesantren Aulia Cendikia dan Ittifaqiyah. Sementara Al Burhan cenderung menerapkan secara longgar. Dari sini dapat disimpulkan bahwa ukuran suatu pesantren dan paham yang dianut bisa menentukan respon terhadap protokol kesehatan di tengah pandemi COVID-19. 


\section{Pendahuluan}

Sejak awal Desember tahun 2019 virus Corona menggemparkan Wuhan China disusul oleh Thailand yang mengkonfirmasi adanya virus di negeri ini Jepang menjadi negara berikutnya dan dengan cepat keberadaan Virus corona terdeteksi menyebar di banyak negara termasuk Indonesia dengan ditemukannya 2 warga Indonesia terdeteksi tertular virus corona jenis baru ini seusai pertemuannya dengan warga Jepang pada tanggal 14 Februari 2020 (Arnani, 2020). Masing-masing negara mencoba menanggulangi virus ini dengan berbagai macam cara. Antara lain, mulai dari langkah pelarangan keluar negeri, pencegahan masuknya warga asing, pembatasan sosial, penerapan protokol kesehatan, lockdown antar daerah, penutupan rumah ibadah dan anjuran ibadah di masjid hingga meliburkan sekolah (Zakaria, 2021).

Di sektor pendidikan, pemerintah Republik Indonesia mengeluarkan peraturan berupa Keputusan Bersama Empat Menteri, Tentang Panduan Penyelenggaraan Pembelajaran Pada Tahun Ajaran 2020/2021 di Masa Pandemi Corona virus Disease 2019 (COVID-19) no 440-882 Tahun 2020. Peraturan tersebut dibuat karena pertimbangan kesehatan dan keselamatan semua warga Indonesia baik sebagai peserta didik, pengajar, hingga pengelola sekolah agar terhindar dari terpaparnya wabah virus berbahaya ini. Menteri Pendidikan dan Kebudayaan (Mendikbud) Nadiem Anwar Makarim mengatakan, "Prinsip dikeluarkannya kebijakan pendidikan di masa Pandemi COVID-19 adalah dengan memprioritaskan kesehatan dan keselamatan peserta didik, pendidik, tenaga kependidikan, keluarga, dan masyarakat." (Kemdikbud, 2020).

Kondisi pandemi yang menuntut untuk menjaga jarak, mengurangi intensitas berkumpul hingga pelarangan dalam berkumpul dan kewajiban untuk selalu memperhatikan protokol kesehatan bisa jadi akan sangat menghambat terlaksananya arah pendidikan santri. Hal itu tidak dapat dipungkiri, mengingat hampir mustahil pelaksanaan pendidikan pesantren tanpa pondok atau asrama dan tanpa bimbingan langsung dengan Kiainya. Artinya, adalah mustahil diberlakukannya pembelajaran dari rumah work from home secara total diberlakukan bagi seluruh santri seperti di sekolah-sekolah umum non pesantren. Hal inilah yang menjadi alasan mengapa banyak pesantren-pesantren yang harus tetap buka, melaksanakan proses belajar mengajar meskipun pesantren-pesantren itu berada di zona merah.

Pendidikan pesantren tidak akan terlaksana ketika tidak ada kepondokan atau asrama yang menjadi ciri khasnya maka, pendidikan pesantren akan susah memenuhi ketentuan zonasi di atas. Oleh sebab itu, bagi pesantren berlaku tiga ketentuan panduan. Tiga kategori itu ialah pesantren yang sudah melakukan pembelajaran tatap muka; akan menggelar pembelajaran tatap muka; dan belum melaksanakan kegiatan belajar tatap muka. Ketiga ketentuan tersebut pada intinya, melibatkan gugus tugas penanggulangan COVID-19 dan bekerja memastikan terlaksananya protokol kesehatan berjalan dengan baik dan melaksanakan pengawasan pada kondisi kesehatan seluruh warga pesantren tanpa kecuali.

Sementara di sisi lain, dalam diskursus agama dan sains, respon terhadap virus ini ditanggapi secara berbeda di antara masyarakat muslim. Respon-respon itu secara garis besar dibagi menjadi dua. Pertama, adalah sikap acuh tak acuh terhadap keberadaan virus dan juga cara cara pencegahannya. Kedua, adalah sikap peduli dan terlibat aktif melakukan upaya pencegahan penyebaran virus. Penelitian ini bertujuan untuk melihat respon pesantren terhadap penularan COVID-19. Alasannya, pesantren sebagai lembaga pendidikan keagamaan kemungkinan besar memiliki respon yang berbeda terhadap eksistensi COVID-19 berikut cara cara pencegahannya.

Selanjutnya, penelitian ini juga akan membahas mengenai respon pesantren terhadap peraturan SKB 4 menteri terkait pelaksanaan protokol kesehatan di satuan pendidikan, sudah siapkah pesantren melaksanakan ketentuan itu semua? Apa kendala yang dihadapinya? Atau adakah success story atau cerita sukses yang dapat dibagikan untuk diterapkan kepada pesantren lainnya.

Penelitian ini akan akan menggali respon pesantren terhadap pandemi dan bagaimana penanggulangan COVID-19 dilakukan di lingkungan pesantren? Untuk menjawab 
pertanyaan di atas, maka penelitian ini akan memilih 3 Pondok Pesantren di wilayah Sumatera Selatan. Pondok pertama, AlIttifaqiah yang berada di desa Indralaya Kabupaten Ogan Ilir Sumatera Selatan. Pesantren ini dapat dikatakan pesantren terbesar di Sumatera Selatan. Pesantren ternama ini termasuk pesantren yang cukup ketat mengikuti arahan pemerintah dalam menghambat penyebaran COVID-19 tapi bagaimana dengan penyelenggaraan pendidikan yang harus mengalami perubahan drastis inilah yang menarik peneliti untuk mengkajinya dalam sebuah format penelitian. Selain itu, pesantren lain yang menjadi subjek kajian adalah Pesantren Al Burhan di Kota Palembang. Pesantren ini dipilih karena memiliki afiliasi dengan paham keagamaan Jamaah Tabligh. Sebagaimana banyak diketahui, Jama`ah Tabligh sempat menjadi klaster penyebaran COVID-19 awal di Indonesia ketika gerakan ini mengadakan Ijma' Tabligh di Gowa Sulawesi Selatan pada pertengahan Maret 2020. Pesantren selanjutnya adalah Pesantren Aulia Cendekia berbasis NU. Ketiga pesantren di atas berada di Palembang disebabkan Palembang merupakan daerah dengan penyebaran COVID-19 yang banyak di Sumatera Selatan.

\section{Tinjauan Pustaka}

Penelitian ini berupaya untuk menyajikan alternatif diskursus yang berkembang mengenai tema agama dan sains dalam konteks pandemi COVID-19. Kebanyakan penelitian yang mengkaji respon agama terhadap pandemi ini menyimpulkan terdapat dua garis besar sikap umat beragama terhadap pandemi.

Pertama, adalah kelompok yang bersikap tidak peduli (ignorance) terhadap perkembangan sains dalam pencegahan COVID-19, dan mereka yang mengakomodasi perkembangan sains dan melakukan langkah-langkah strategis dalam pencegahan. Seperti penelitian (Kuswana, Qomaruzzaman, \& Mahatma, 2020) mengungkapkan sikap ulama Jawa barat terhadap COVID-19. Masih terkait dengan sikap para ulama, (Arrobi \& Nadzifah, 2020) juga mengungkapkan sebagian kecil ulama "selebritis" awalnya bersikap menolak temuan sains bahwa virus ini dapat menyebar pada siapa saja dengan mengatakan bahwa
COVID-19 adalah tentara Allah SWT sebagai hukuman bagi China atas penderitaan Muslim Uighur. Meski akhirnya terjadi perubahan sikap.

Sementara riset lainnya seperti riset (Darmawan, Miharja, Waluyajati, \& Isnaeniah, 2020; Kemenag, 2020) meneliti tentang respon umat muslim di Indonesia terkait dengan perilaku beribadah di era Pandemi. Hasilnya, terdapat sekitar 20\% masyarakat muslim tetap melaksanakan ibadah dengan mengabaikan anjuran social distancing sementara $80 \%$ mayoritas muslim di Indonesia mematuhi anjuran pemerintah dalam pembatasan sosial termasuk dalam beribadah. Masih mengenai dikotomi sikap agama terhadap Pandemi, penelitian (Hadi, 2020) mengungkapkan dikotomi sikap itu juga ditemukan di masyarakat Desa Ploso Ngawi. Penelitian-penelitian di atas lebih menekankan pada bagaimana institusi agama seharusnya bersikap dalam menghadapi pandemi, atau dengan kata lain institusi agama harusnya juga tunduk terhadap pencegahan penyakit dari perspektif medis.

Sebaliknya, institusi agama yang berperan pada pencegahan COVID-19 adalah mereka yang turut andil bagian untuk mempromosikan anjuran pemerintah terkait pencegahan penularan penyakit dalam perspektif kesehatan tentunya. (Aula, 2020; Mushodiq \& Imron, 2020). Penelitian di atas tidak melihat bagaimana peran pesantren dalam mengatasi persoalan-persoalan ekonomi dan sosial keagamaan khususnya di kalangan masyarakat.

Mengenai kesulitan-kesulitan yang dihadapi oleh pesantren di tengah pandemi terdapat penelitian (Kahfi \& Kasanova, 2020) yang melihat persoalan yang dihadapi pesantren selama masa pandemi dari sudut pandang manajemen pendidikan. Kesulitannya adalah pelaksanaan aktivitas pengajaran, dan solusi yang dilakukan pesantren dalam mengatasinya (Dhofier, 1980; Sastry \& Basu, 2020). Berbeda dari penelitian-penelitian di atas, penelitian ini mencoba untuk melihat perspektif lain mengenai kesulitan-kesulitan dan peran institusi agama di tengah pandemi terkait persoalan-persoalan sosial dan ekonomi. 


\section{Metodologi Penelitian}

Jenis penelitian yang digunakan pada penelitian ini adalah penelitian fenomenologis, yaitu menggambarkan fenomena secara apa adanya (Saebani, 2008). Secara spesifik fenomena yang dikaji berupa respon teologis dan juga perilaku pihak pesantren dalam penerapan protokol kesehatan. Fenomena yang digambarkan terbagi menjadi dua, perspektif dan perilaku. Perspektif yang diteliti antara lain. Pertama, pandangan agama (teologis) pihak pesantren terkait dengan hubungan COVID-19 dan Kehendak Allah SWT, Juga terkait sikap manusia dalam menghadapi kehendak Allah SWT. Kedua, terkait dengan perspektif atau sudut pandang lainnya dalam melihat COVID-19, baik dari sudut pandang ekonomi, sosial dan politik. Teknik pengumpulan data untuk melihat perspektif ini kebanyakan didapat melalui wawancara. Sedangkan dalam memverifikasinya akan dicari dari observasi dan dokumentasi. Sementara perilaku dilihat mengenai perilaku mereka dalam penerapan protokol kesehatan COVID-19. Teknik pengumulan datanya dilakukan baik melalui dokumentasi, observasi dan wawancara (Arikunto, 1992). Teknik analisis dan verifikasi data dilakukan dengan melihat konsistensi ucapan terhadap perilaku yang dinampakkan di lingkungan pesantren.

\section{Hasil dan Diskusi}

\section{a. Pemahaman Keagamaan Pesantren AlIttifaqiah Terkait Pandemic COVID- 19}

Pandangan para pengelola terhadap pandemi COVID-19 tidak sama, hal ini sangat mungkin terjadi karena background pendidikan, budaya dan sosial mereka yang bermacam-macam. Mereka berpandangan bahwa COVID-19 merupakan musibah bagi dunia yang menuntut manusia untuk banyak berintropeksi diri. Adapun pandangan lainnya menyebutkan bahwa COVID-19 merupakan ujian bagi orang yang beriman, sebagaimana firman Allah SWT dalam Surah Al-Ankabut yang artinya:

"Apakah manusia mengira bahwa mereka akan dibiarkan hanya dengan mengatakan: "Kami telah beriman", dan mereka tidak diuji? [Q.S Al-Ankabut (29):2]
Sementara salah satu ustadz beranggapan bahwa COVID-19 merupakan takdir dengan argumentasi bahwa apa yang sudah disampaikan dari medis ataupun WHO terbantahkan. Sebagai contoh bahwa penularan melalui interaksi dengan orang yang terpapar COVID-19 tapi banyak dalam satu keluarga yang anggotanya terpapar COVID-19 tidak menular pada anggota lainnya termasuk yang terjadi pada keluarganya sendiri (NA, 2021).

Sementara pendapat lainnya lebih menekankan bahwa yang terpenting adalah sikap yang seharusnya diambil, bila COVID19 adalah mushibah berarti Allah SWT sedang melatih kesabaran, dalam arti kita ditegur untuk tetap setia berjalan di jalan-Nya saat berhadapan dengan ketidaknyamanan pandemi ini sehingga Allah SWT akan memberi imbalan atas kesabaran, bila itu azab berarti Allah SWT sedang membersihkan manusia dan semesta agar kemudian bisa peka merasakan manis dan segarnya hidup dijalan dengan polanya, bila ini ujian maka itu cara Allah SWT agar manusia belajar hidup menurut mau-Nya sehingga ia bisa naik level dalam kualitas kehambaannya di mata Allah SWT (UK, 2021).

Pernyataan resmi yang mewakili sikap pondok pesantren al-Ittifaqiah adalah "Kuatkan iman dan imun jangan abai dan jangan berlebihan" disampaikan oleh mudir pondok pesantren Al-Ittifaqiah Drs K. Mudrik Qori, MA, dalam banyak kesempatan. Pernyataan ini mengandung makna himbauan untuk tidak meremehkan keberadaan dan bahanya seperti ungkapan COVID-19 itu tidak ada, mati ditangan Tuhan COVID-19 atau tidak kalau mau mati yah mati juga dst sementara kata berlebihan bermakna sampai takut bersosialisasi kata Ust Khazin salah seorang guru madrasah Aliah Al-Ittifaqiah saat di wawancarai di ruang guru madrasah Aliyah.

Tidak boleh berlebihan berarti tidak boleh terlalu ditakuti hingga santri tidak belajar begitu juga dengan walinya muncul kekhawatiran terhadap keselamatan anaknya, tapi tetap waspada jangan terlalu santai (UA, 2021).

Dari beberapa informais yang didapat peneliti menarik kesimpulan ada perbedaan sudut pandang antara beberapa pernyataan yang muncul di awal datangnya COVID-19 yang menganggap bahwa ini adalah hukuman 
Allah SWT atas kedhaliman orang China terhadap warga Muslim disana, dan pendapat bahwa corona hanya akan menimpa orangorang durhaka atau kalau menimpa kaum muslimin pasti mereka adalah muslim yang berdosa sementara pernyataan para pengelola pesantren Al-Ittifaqiah lebih kepada pandangan bahwa ini adalah musibah atau ujian bagi dunia yang memerlukan intropeksi diri sehingga Tindakan hati-hati dan waspada namun tetap bersikap wajar adalah jalan yang dipilih untuk diambil oleh para pengelola guru, santri dan wali santri.

Terkait respon pengelola pesantren AlIttifaqiah dalam menghadapi masalahmasalah sosial dan ekonomi yang dihadapi selama pandemi seperti beragamnya tanggapan terhadap keberadaan COVID-19 perbedaan juga terlihat dalam merespon masalah sosial dan ekonomi yang memunculkan beragam tanggapan pengelola pesantren Al-Ittifaqiah salah satunya beranggapan bahwa "Pandemi ini memang ada orang kesehatan mungkin lebih bisa membuktikan itu secara sains namun dalam aksiologinya banyak pihak yang bisa diajak berbicara untuk mencari solusi bukan hanya pemerintah, menurutnya pemerintah dalam masalah COVID-19 ini berlebihan terutama dalam memberikan kampanye terhadap dampak COVID-19 dan digiring pada kepentingan tertentu seperti kepentingan bisnis contohnya ketika COVID-19 ini dianggap sebagai pandemi tetapi perlakuan negara tidak seperti sedang berhadapan dengan pandemi ketika di luar negeri sudah mencabut status ini bahkan kini dianggap sebagai penyakit biasa dimana yang sakit ditangani yang tidak sakit dipersilahkan untuk hidup normal sementara saya melihat ada sekolompok orang yang bertaruh dengan modal yang sudah dikeluarkan yang jelas rakyat dirugikan bila seandainya pemerintah konsisten dengan pernyataan bahwa ini pandemi maka yang akan menanggung bebannya yang berat justru pemerintah dan pengusaha dan rakyat akan enak, tapi realitanyakan seperti yang meraup keuntungan dari korban COVID-19 adalah rumah sakit bukan masyarakat. Perlakuan PPKM bila konsisten akan menguntungkan karyawan dan merugikan pengusaha karena mereka harus berhenti bekerja sementara gajih harus dibayarkan maka rakyat akan santai dan diuntungkan dengan kebijakan tersebut namun nyatanya tidak" (NF, 2021).

Pengelola pesantren Al-Ittifaqiah menyadari kondisi yang sedang menimpa masyarakat khususnya yang berhubungan langsung dengan PPI seperti para guru, karyawan santri, dan wali santri yang mengalami kondisi yang tidak diinginkan oleh seluruh warga dan keluarga besar PPI berupa ketidak mampuan untuk mencukupi kebutuhan hidup layak di pesantren karena harga bahan pokok dan lauk pauk juga sayuran yang naik selam apandemi COVID19 juga hambatan dalam pengaturan, distribusi logistik karena kurangnya pemasukan dari pembayaran uang asrama dan uang makan, akibat dari pemutusan hubungan kerja yang dialami sebagian wali santri atau tidak sampai di PHK namun dikurangi jam kerjanya dan gajinya, atau gaji yang terhambat maka dengan tetap membuka proses belajar tatap muka dengan protokol kesehatan yang ketat masalah sosial yang kerap muncul seperti kehilangan pekerjaan, menganggur, pemotongan gajih karyawan anak berhenti sekolah karena tidak ada biaya tidak terjadi sama sekali di Pesantren Al-Ittifaqiah, para buruh cuci tetap bekerja, bagian logistik, tukang sapu, tukang buang sampah, juga bisa tetap bekerja dan guru serta karyawan tidak terbebani dengan bayaran yang besar bila anaknya disekolahkan di Pesantran AlIttifaqiah karena mereka mendapatkan dispensasi pembayaran 100 \%Tidak kalah pentingnya kemunculan rasa khawatir yang berlebihan yang dapat menurunkan daya tahan tubuh yang juga masalah sosial tidak terlepas dari pandangan pengelola pesantren itu sebabnya ungkapan jangan berlebihan menghadapi COVID-19 juga selalu didengungkan seiring dengan ungkapan agar tetap berhati-hati dengan ungkapan "jangan abai". Semula menurut satgas COVID-19, warga pondok (guru, pengelola, santri dan semua yang terlibat didalamnya) tampak khawatir berlebihan namun setelah mendapatkan pencerahan dari pimpinan tertinggi keresahan dan kekhawatiran itu dapat diatasi dengan baik sehingga kehidupan tanpak normal seperti biasanya.

\section{b. Pemahaman Keagamaan Pesantren Aulia Cendikia Terkait Pandemic COVID-19}


Di awal pandemi, sangat santer mengenai pandangan atas merebaknya Virus COVID-19 sebagai bentuk hukuman Allah SWT atas kedhaliman orang China terhadap warga Muslim Rohingnya. Selanjutnya bahwa corona hanya akan menimpa orang-orang durhaka atau kalau menimpa kaum muslimin pasti mereka adalah muslim yang berdosa, Namun begitu pandangan ini segera hilang karena ternyata pandemi ini juga melanda umat muslim di Indonesia. Dari beberapa pernyataan para pengelola pesantren Aulia Cendikia, mereka lebih kepada pandangan bahwa ini adalah musibah atau ujian bagi dunia yang memerlukan intropeksi diri .

Bagi KH Hendra Zainuddin, COVID-19 merupakan takdir Allah SWT. Baginya, apa yang ada di dunia adalah ciptaan Allah SWT atau punya Allah SWT. Allah SWT akan mendatangkan nikmat atau bala', baik atau buruk kepada suatu makhluk adalah kehendaknya. Baginya, Corona adalah makhluk Allah SWT, sebahaya apapun penyakit ini pasti Allah SWT memiliki hikmah tersendiri. Allah SWT menciptakan COVID-19 di muka bumi ini atas kehendak dan takdir-Nya.

Allah SWT mempunyai maksud serta hikmah di atas segala kejadian yang menimpa dunia, dan sebagai hamba-Nya yang beriman, sebaiknya menyikapi COVID-19 dengan tenang bukan meratapinya, melainkan berikhtiar dalam mencegahnya dengan segala kemampuan dan usaha yang dapat dilakukan

Hikmah yang langsung dirasakan menurut mudir Aulia Cendikia itu adalah bertambahnya wawasan dan pengetahuan tentang COVID-19. mudir mengaku bahwa sebelum pandemi, dirinya tidak mengerti apaapa tentang COVID-19, hanya mendengar apa yang ada di berita dan masih simpang siur. Hal ini wajar, pada awal pandemi banyak yang tidak tahu menahu mengenai virus ini. Bahkan pejabat negara setingkat menteri kesehatanpun, melontarkan pandangannya terkait tentang COVID-19 yang justru bertentangan dengan perkembangan sains yang ada. Pengetahuannya tentang virus ini banyak didapatkannya melalui keterlibatannya dalam organisasi NU. Artnya, memang NU merupakan organasisasi yang secara aktif mengkampanyekan pencegahan penularan virus ini.

Organisasi ini mengedepankan sikap wasathiyah (moderat) dalam bersikap terhadap perbedaan. Di dalam Ahlus Sunnah wal Jamaah, terdapat dua kutub ekstrim dalam memahami takdir, yakni jahmiah dan qadariyah. Jahmiyah berpandangan bahwa apapun yang dilakukan dan terjadi pada manusia sepenuhnya merupakan kehendak Allah SWT. Sedangkan qadariyah berpandangan bahwa apapun yang terjadi adalah akibat dari perbuatan manusia di dunia, atau perbuatan manusia bukanlah kehendak atau ciptaan Allah SWT.

Sementara NU, sebagai organisasi yang beraliran moderat atau wasathiyah memang mendasari pemahaman teologinya berdasarkan pemahaman Asyariyah dan Maturidiyah. Dalam teologi Asyariyah, seluruh yang baik atau buruk datangnya dari Allah SWT. Seluruh yang ada di dunia ini merupakan ciptaan Allah SWT. Meskipun begitu, manusia masih memiliki kehendak dalam perbuatannya untuk menghindari keburukan dan melakukan kebaikan, atau sebaliknya menjerumuskan diri pada keburukan dan menghindari kebaikan.

Di sini nampak jelas, teologi ini mengambil jalan tengah antara teologi Jahmiyah dan Qadariyah. Teologi Asyariyah berasal dari ulama bernama Abul Hasan al Asyari atau Imam Asyari. Menurut Imam Asyari, manusia masih memiliki kehendak bebas (free will) untuk berbuat baik ataupun buruk, namun semua yang dilakukan manusia itu masih dalam ketetapan Allah SWT. Seperti Allah SWT mengatur adanya baik dan buruk, dan Allah SWT juga menetapkan konsekuensi atas perilaku manusia. Manusia masih bisa berkehendak bebas, namun tetap harus menanggung konsekuensi yang ditetapkan Allah SWT.

Apa yang dikatakan oleh $\mathrm{KH}$ Hendra Zainuddin, memang tampak merefleksikan teologi yang dipegang oleh NU bahwa apapun yang ada adalah ciptaan Allah SWT, termasuk COVID-19. Jika virus ini merupakan hal yang buruk, maka manusia masih memiliki kehendak untuk menghindarinya dengan ikhtiar. Beliau juga menolak pandangan bahwa virus ini adalah azab. Menurutnya azab sudah berhenti pada masa Rasulullah Muhammad Saw.

Pandangan para pengelola terhadap COVID-19 tidak banyak perbedaan dalam merespon COVID-19 secara teologis. Pandangan yang hampir sama juga datang dari seorang ustadzah yang beranggapan bahwa 
COVID-19 merupakan musibah bagi dunia yang menuntut kita banyak berintrospeksi diri. Dengan adanya penyakit ini, justru menjadi kesempatan bagi manusia untuk selalu bertafakkur, merenungi diri atas kesalahan atau dosa-dosa yang telah dilakukannya selama ini. Dengan adanya pandemi ini, menurutnya banyak orang yang meninggal, dan manusia tidak akan pernah tahu kapan gilirannya. Sehingga dengan adanya pandemi ini, manusia dituntut untuk terus berdoa dan mendekatkan diri kepada Allah SWT (UN, 2021).

Sementara pendapat lainnya menganggap COVID-19 adalah takdir, dan apapun yang dilakukan manusia tidak dapat menghindarkan diri mereka dari takdir Allah SWT yang telah ditetapkannya. Kepercayaaan bahwa segala macam kejadian, termasuk sehat sakit, hidup dan mati adalah kehendak-Nya, tidak ada yang mampu untuk melawan apa yang sudah ditetapkan (FT, 2021).

Pendapat tersebut nampak sedikit berbeda dengan apa yang disampaikan oleh $\mathrm{KH}$ Hendra Zainuddin. Menurut beliau manusia sebaiknya berikhtiar dengan cara menuruti saran-saran dari ahlinya dalam menghindari COVID-19. Menurutnya, mempercayai saran atau ahli dalam hal ini adalah dokter, tenaga medis dan Kementerian Kesehatan.

Dari beberapa informasi yang didapat peneliti menarik kesimpulan ada perbedaan sudut pandang secara teologis terhadap COVID-19. Di antara mereka ada yang menganggap penyakit ini sebagai musibah, ada juga yang memandangnya sebagai cobaan. Kedua pandangangan ini masih menaruh perhatian pada ikhtiar manusia untuk dapat menghindarinya, selain itu kedua pandangan ini masih percaya bahwa Allah SWT memberikan hikmah atas peristiwa yang terjadi. Selanjutnya, sebagian besar para pengelola pesantren meyakini bahwa COVID19 merupakan takdir Allah SWT. Hal ini berdasarkan teologi dalam Ahlussunnah wal Jama`ah. Meskipun begitu, terdapat perbedaan dalam menyikapi takdir. Pandangan Pertama, masih menisbatkan usaha atau ikhtiar manusia dan menyerahkan urusan penyakit ini kepada ahlinya. Sementara pandangan Kedua, lebih cenderung bersikap fatalisme, bahwa apapun yang terjadi adalah kehendak Allah SWT dan tidak ada yang sanggup untuk menentang atau mengubah apa yang sudah digariskannya.
Selain itu, apapun yang terjadi di dunia ini hanya sementara, sama seperti halnya kehidupan, dari dahulu silih berganti datang pandemi yang mengguncang dunia, seperti halnya penyakit lepra, TBC, demam berdarah, cikungunya dan sebagainya. Seluruh penyakit selalu dapat ditangani. Segala macam penyakit ada obatnya. Pandemi COVID-19 hanya bersifat sementara dan sebagai orang beriman harus yakin untuk dapat melaluinya.

Selain respon mereka mengenai pandemi dalam persepsi teologis, Beberapa meresponnya dengan perspektif sosial ekonomi dan politik. Perspektif sosial ekonomi yang dibicarakan berkisar mengenai dampak yang terjadi di masyarakat. Sementara responnya soal politik, berkisar mengenai kritik mereka terhadap pemerintah. Terkait respon itu, setiap pengelola pesntren memilih tanggapan yang berbeda beda. Jika pimpinan Pondok, KH Hendra Zainuddin lebih merespon pada perspektif sosial ekonomi dengan lebih positif. Sementara yang lain membicarakannya dengan perspektif politik yang lebih bersifat kritis.

$\mathrm{KH}$ Hendra Zainuddin menganggap bahwa Pandemi memang membuat perekonomian sebagian masyarakat terpuruk banyak masyarakat yang terkena PHK, dikuranginya jam kerja yang berakibat berkurangnya pendapatan. Selain itu, kebijakan karantina mandiri atau karantina wilayah membuat banyak orang kehilangan penghasilannya. Meski demikian menurut beliau, pandemi ini tidak pernah membuat orang atau masyarakat Indonesia meninggal karena kelaparan. Di awal pandemi banyak orang yang takut mati kelaparan terjadi. Namun ketakutan itu hanyalah reaksi emosional. Masyarakat Indonesia terbiasa untuk bergotong-royong, bantu-membantu terhadap sesama ketika yang lain mengalami kesulitan ekonomi. Menurutnya, solidaritas yang tinggi pada masyarakat Indonesia, selalu membuat bangsa ini bisa selamat dari persoalan ekonomi. Dalam tanggapannya, beliau tidak menyinggung pemerintah, tidak memuji ataupun mengkritik pemerintah terkait penanganan COVID-19 (HZ, 2021).

Menurutnya banyak hikmah yang dapat diambil dari COVID-19. Di antaranya banyak orang mulai dapat beradaptasi dengan polapola baru utamanya di dunia digital. Dari COVID-19 ini banyak orang yang mulai terpacu untuk menyesuaikan dirinya melalui 
perkembangan teknologi digital yang ada seperti webinar, zoom meeting dan sebagainya. Baginya ini kondisi positif bagi perkembangan masyarakat baik secara kapasitas kemampuan digitalnya, maupun perekonomian, seperti hidupnya perekonomian masyarakat yang menyediakan layanan jasa pulsa internet, data, dan sebagainya. Sehingga menurutnya, persoalan ekonomi ada dampak positif dan negatifnya, dan itu semua merupakan ujian dari Allah SWT.

Pandangan berbeda disampaikan oleh salah satu tenaga pendidik. Responnya lebih berupa kritik terhadap pemerintah. ketika COVID-19 ini dianggap sebagai pandemi di awal pemerintah tidak segera melakukan karantina wilayah, dan terkesan cuek, berbeda dengan negara lain yang sudah memproteksi merebaknya wabah ke negara mereka. Sebaliknya ketika negara lain sudah mulai berani melonggarkan aturan pandemi atau di luar negeri sudah mencabut status darurat dan bahkan kini dianggap sebagai penyakit Indonesia justru mengetatkan aturannya (BK, 2021).

Mengenai bagaimana bersikap dalam menghadapi pandemi, seluruh pengelola pesantren Aulia Cendikia berpendapat untuk selalu tenang menghadapinya. Mereka memberi saran kepada seluruh lapisan masyarakat untuk tidak takut dan panik. Waspada terhadap penularan adalah penting. Tidak menyepelekan anjuran mengenai protokol kesehatan. Protokol kesehatan harus tetap dijalankan bagaimanapun kondisinya. Meski begitu, dalam bersikap harus tenang dan tidak panik, tetap melakukan aktifitas seperti biasa sambil terus mematuhi protokol kesehatan.

\section{c. Pemahaman Keagamaan Pesantren Al Burhan Terkait Pandemic COVID-19}

Perilaku Jamaah Tabligh yang menyelenggarakan konferensi "ijtima" di awal penyebaran pandemi pada tahunn 2020 lalu memang bertentangan dengan Fatwa MUI No 14 ahun 2020 tentang Implementasi Peribadatan selama Masa Pandemi. Jamaah Tabligh menyelenggarakan ijtima' pada tanggal 13 Maret 2020 di Petailing Jaya Selangor Malaysia. Acara itu dihadiri sekitar 16.000 orang dari seluruh dunia. Dari jumlah tersebut diketahui bahwa 700 di antaranya merupakan kluster penyebaran dari Indonesia.
Fraksi lain dari Jamaah Tabligh, dalam waktu yang hampir bersamaan juga menyelenggarakan ijtima' yang bertempat di Darul Ulum Pesantren Pakatto di Kabupaten Gowa Sulawesi Selatan. Jumlah peserta yang hadir pada acara itu lebih besar lagi sekitar 19.963 orang. Pertemuan itu kemudian menjadi kluster penyebaran yang cukup masif di Indonesia.

Kejadian itu sedikitnya menunjukkan bahwa Jema`ah Tabligh tidak mengikuti arahan pemerintah dalam penanganan COVID-19. Jamaah Tabligh hanya menyeru kepada dakwah amar ma'ruf, dan tidak ada tendensi politik sama sekali. Namun yang jelas, di sini akan dilihat lagi sebenarnya bagaimana konstruksi Jamaah Tabligh terhadap pandemi dan bagaimana juga perilaku mereka terhadapnya, apakah masih sama antara awal COVID-19 dan saat penelitian ini ditulis. Jika masih sama lantas apa yang mendasari sikap dan perilakunya ini.

Sekian banyak tulisan dan ceramah yang menarasikan bahwa penyakit ini adalah siksaan Tuhan, lebih-lebih pada awal penyebarannya di China. Memang pada mulanya banyak yang menerima pandangan tersebut, apalagi hal tersebut dikaitkan dengan kepercayaan, makanan, gaya hidup bahkan politik penduduk dan pemerintahan China. Tetapi setelah menyebar ke beberapa negara termasuk negara-negara bermasyarakat muslim dan menyerang pula kaum muslimin yang taat, maka pandangan tersebut mulai sirna walau masih ada saja yang menganutnya.

Hal ini tidak dapat dinamai siksa Ilahi karena menimpa muslim dan non muslim yang durhaka maupun taat. Dari Al-Qur'an diperoleh kesan yang cukup kuat bahwa jika Allah SWT hendak menjatuhkan siksa atas satu kaum, maka terlebih dahulu diselamatkan hamba-hamba yang taat agar mereka tidak ditimpa siksa. Itu terbaca dengan jelas ketika Allah SWT hendak menjatuhkan siksa-Nya kepada umat Nabi Nuh a.s Allah SWT memerintahkan nabi mulia untuk membuat perahu guna mengangkut kaum beriman sebelum datangnya banjir besar, seperti yang diterangkan dalam QS. Hud ayat 26-27. Demikian itulah halnya jika bencana berupa siksa, tetapi jika bencana yang menimpa menyentuh yang durhaka dan taat maka bencana tersebut dinamai fitnah atau bala. 
Kedua kata ini digunakan oleh Al-Qur'an dalam arti ujian atau cobaan.

Pandangan para pengelola pesantren terhadap COVID-19 tidak sama antara satu dengan lainnya. COVID-19 merupakan ujian bagi orang yang beriman, dan menganggap apakah orang beriman itu mampu mempertahankan imannya atau tidak, ujian kepada orang yang beriman untuk terus atau justru lalai dalam kewajiban agamanya. Orang bisa saja dibuat lalai dalam mengerjakan amal ibadah, seperti meninggalkan shalat Jum`at karena alasan pandemi. Dari sini dapat dilihat bahwa Jamaah Tabligh sangat resisten terhadap isu COVID-19 sebagai penyakit menular berbahaya.

Beberapa ustadz lain, menganggap bahwa sebenarnya virus ini merupakan bentuk konspirasi yang dilakukan oleh Barat agar terjadi perpecahan pada diri umat Islam selain itu, ada potensi juga virus itu akan membuat umat Islam lalai terhadap agama. Sebagaimana sebuah video ceramah dari Ustad Rahmat Baequni yang berjudul "Adakah Konspirasi dibalik Corona?", di dalam video tersebut Ustad Rahmat Baequni mengatakan manusia memiliki kemampuan untuk menciptakan ini (COVID-19) konspirasi dan berakibat pada perpecahan ditengah-tengah umat Islam, Virus ini dapat mengakibatkan fitnah yang dasyat (US, 2021).

Informan lain, dari seorang pengurus pesantren mengungkapkan tentang COVID19 sebagai ujian namun dengan narasi yang lain, bahwa ujian ini adalah cara Allah SWT memberikan tantangan kepada umat Islam agar berlatih sabar, ikhlas, dan menunjukkan kekuasaan-Nya. Menurutnya, masa pandemi ini ada banyak yang mengalami kesulitan ekonomi, juga ujian karena diberikan sakit. Maka dari itu orang akan berlatih untuk sabar dan ikhlas. Tidak ada yang bisa melawan kehendak Allah SWT, yang bisa dilakukan adalah berusaha dan berikhtiar untuk menghindarinya. Menurutnya di masa-masa sulit seperti ini justru menjadi kesempatan bagi seorang muslim untuk memperbanyak mendekatkan diri kepada Allah SWT dengan cara berdzikir dan bertafakkur terhadap-Nya. "pandemi ini seharusnya menjadi moment yang tepat untuk memperbaiki amalan. Hal ini dapat dilakukan dengan senantiasa mendekatkan diri kepada Allah SWT. Maka sebagai umat manusia yang beriman, kita dianjurkan untuk ikhlas dan sabar dalam menghadapi kondisi ini. kesabaran ini juga menjadikan tolak ukur keimanan seseorang karena telah diuji" (UT, 2021).

Di awal-awal pandemi, terdapat video viral yang beredar diucapkan oleh seorang Amir dari Jamaah Tabligh yang mengatakan bahwa seharusnya tidak boleh takut terhadap Corona, karena yang ditakuti seharusnya Allah SWT . Jangan sampai virus ini membuat manusia menjadi syirik. Dalam video itu juga yang memancing kontroversi adalah pernyataannya "Corona itu takut kepada para Jamaah, bukan jamaah yang takut pada virus, jamaah hanya takut kepada Allah SWT, itu dakwah namanya".

Dari pernyataan-pernyataan diatas dapat dikategorikan kedalam dua kategori yaitu pandangan yang mempercayai bahwa virus COVID-19 itu memang ada dan pandangan yang menganggap bahwa COVID-19 diciptakan oleh manusia dan membuat umat Islam khususnya lalai terhadap Allah SWT dan agama.

Pendapat yang tidak percaya bahwa virus itu ada dengan argumen bahwa penyakit orang yang terdeteksi Corona itu sama saja dengan penyakit-penyakit yang sudah ada sebelumnya dan banyaknya kasus-kasus yang membuat pasien seolah-olah COVID-19, padahal riwayat penyakit yang dideritanya jelas dengan tujuan agar dapat segera menyerap anggaran pemerintah yang dikhususkan untuk menangani penyakit itu yang asalnya justru dari hutang luar negeri dan pajak rakyat turut mengukuhkan pendapat ini.

Sebagian anggota juga berpendapat bahwa pandemi COVID-19 adalah upaya konspirasi dari umat lain (Yahudi dan Kristen) untuk melemahkan Islam. Menurutnya penyakit ini tidak kasat mata, namun musuh yang nyata jelas ada di depan mata. Banyak di antara mereka yang memiliki sikap acuh tak acuh terhadap keberadan COVID-19 karena tidak ada pengetahuan terhadap hal itu. Hal ini diakibatkan kurangnya edukasi mengenai apa bahayanya virus tersebut.

Edukasi yang ada sebenarnya masih terbatas di media media. Ada di antara mereka yang memang sepenuhnya menghindari kemajuan teknologi, tidak mengakses internet dan ataupun sosial media. Perilaku seperti ini masih ada di antara anggota Jamaah Tabligh di Palembang. Sehingga tidak heran ada juga yang berpikiran bahwa penularan COVID-19 
masih bisa dihindari hanya dengan menjauhkan diri dari penderita saja.

Berdasarkan observasi yang peneliti lakukan di pesantren dan masjid $\mathrm{Al}$ Burhan terlihat jarang sekali ada jamaah yang memakai masker. Ada sikap dan perilaku yang menunjukkan ketidak pedulian terhadap COVID-19. Sikap ini tidak jauh berbeda dengan pada masa awal pandemi yang mana mereka melakukan ijma' atau pengumpulan massa yang sangat banyak, dan memilih sikap berbeda dari fatwa MUI dan anjuran dari ormas Islam besar seperti NU dan Muhammadiyah. Dari pengamatan peneliti di masjid Al Burhan sama sekali mereka tidak memenuhi protokol kesehatan, tidak menjaga jarak ketika shalat, jarang sekali di antara para jamaah yang pakai masker, dan tetap dilakukan pengajian yang melibatkan kerumunan masa.

Alasan di balik apa yang mereka lakukan antara lain sebagai berikut. Pertama, bagi Jamaah Tabligh umat Islam adalah umat terbaik yang diutus oleh Allah SWT untuk seluruh umat manusia, karena menyeru kepada kebaikan dan menyeru keimanan kepada Allah SWT. Sehingga bagi Jamaah Tabligh agenda kegiatan seperti muzakarah, ta'lim, bayan dan khuruj, adalah upaya dalam menjalankan kewajiban sebagai umat terbaik itu. Kedua, terkait dengan pelaksanaan ibadah secara berjamaah di Masjid. Bagi Jamaah Tabligh beribadah secara berjama'ah di Masjid adalah kewajiban yang harus dipenuhi oleh laki laki. Baik Al Quran dan hadits menyeru kepada setiap muslim untuk memakmurkan masjid seperti firman Allah SWT dalam Surah At-Taubah yang artinya:

"Masjid-masjid Allah SWT hanya akan dimakmurkan oleh mereka yang percya kepada Allah SWT menegakkan shalat, membayar zakat, dan tidak takut pada apapun selain Allah SWT. Maka mudah mudahan di antara mereka adalah orang orang yang mendapatkan petunjuk" [Q.S At-Taubah (9):19]

Ayat inilah yang menjadi rujukan mereka untuk selalu memakmurkan masjid. Bagi mereka tidak ada alasan apapun untuk meninggalkan ibadah shalat berjamaah di masjid termasuk virus. Mereka juga yakin bahwa dengan berada di masjid, Allah SWT akan menjauhkannya dari segala macam penyakit. Sebagaimana suatu ibadah atau perintah harus didahulukan dan diutamakan daripada bentuk keringanannya. Misalnya, mereka menolak untuk menjaga jarak dalam shaf shalat disebabkan bahwa perintah merapatkan shaf adalah mutlak, dan tidak ada ketetapan yang menggantinya dalam keadaan apapun meskipun terpaksa. Juga tidak ada alasan bagi seorang Muslim untuk meninggalkan shalat Jumat kecuali hal-hal yang telah ditentukan pengecualiannya.

Menurut mereka dalam hal ibadah terutama ibadah mahdhah tidak ada alasan untuk menggantikannya dengan hukum karena adanya persoalan yang bersifat kekinian. Hal lain yang membentuk penolakan mereka terhadap protokol kesehatan yang ditetapkan pemerintah adalah pemahaman terhadap Hadits mengenai tidak menularnya penyakit yaitu hadis yang menginformasikan bahwa penyakit tidak menular, tidak boleh seseorang merasa sial, dan dalam redaksi yang lain menambahkan tidak boleh merasa sial karena melihat burung hantu.

Terkait penularan COVID-19 mereka memahami bahwa sebenarnya tidak ada penyakit yang menular dengan sendirinya semua penyakit itu menular atas kehendak Allah SWT. Mengenai tradisi khuruj yang dijalankannya pada masa Pandemi, orang Jamaah Tabligh menafsirkan hadis tentang dilarangnya bepergian ketika suatu daerah terjangkit Thaun (Penyakit menular) dan dilarang memasuki suatu wilayah yang sudah terjangkit. Apapun kehendak dan keputusan ada di tangan Allah SWT dan tidak ada sebenarnya penyakit menular, syariah memang menuntut kita untuk menghindari penyakit menular. Tetapi sesungguhnya tidak ada penyakit yang bisa menular dengan sendirinya, semua atas kehendak Allah SWT. Nabi Muhammad Saw mengatakan "la adwa" tidak ada penyakit menular yang berarti tidak ada suatu penyakit yang dapat menular dengan sendirinya, semua kehendak Allah SWT"

Lantas baginya, salah satu solusi untuk menghadapi sakit adalah ikhtiar dan berdoa. Doa yang paling baik adalah doa yang diucapkan secara ikhlas dan bersungguh sungguh. Nabi Muhammad Saw telah mencontohkan berbagai macam doa dan zikir untuk keselamatan atas segala penyakit. Jadi jika orang sakit, usaha yang paling baik adalah dengan memperbanyak doa, zikir, ikhtiar dengan memeriksa penyakitnya ke dokter, dan 
minum obat. Di tambahkannya, bahwa jika Allah SWT memberikan penyakit pada diri seseorang, maka yang bisa diupayakan adalah dengan ikhtiar-ikhtiar di atas, dan atas kehendaknya pula atau takdirnya pula seseorang dapat sembuh dari penyakitnya atau meninggal. Dari sini nampak jelas bahwa menurutnya keberadaan COVID-19 adalah takdir yang harus diterima dengan ikhlas, persoalan hidup dan mati ada di tangan Allah SWT.

Dari pandangan ini dapat dilihat bahwa apa yang menjadi konstruksi Jamaah Tabligh atas penyakit, merupakan bentuk diskursus tandingan terhadap diskursus yang sudah mapan. Cara Jamaah Tabligh menafsirkan suatu hadis dilakukan secara tekstual, dengan penafsiran ala sufisme berupa kepasrahan dan ketertundukan secara penuh seorang hamba kepada Tuhannya. Mereka juga yakin bahwa selama ini, kehidupan yang mereka jalani adalah kehidupan yang sehat jika meniru bentuk atau perilaku kehidupan Nabi Muhammad Saw. Jika seseorang meniru kehidupan sehat Rasulullah maka tidak ada penyakit yang mampu membunuhnya, kecuali memang Allah SWT sudah menakdirkannya.

Hadis yang telah disebutkan di atas merupakan referensi mereka terhadap cara menghadapi COVID-19. Penafsiran terhadap itu, didasarkan pada kitab-kitab pegangan dari pesantren Al Burhan. di Pesantren tersebut diajarkan beberapa kitab kitab yang mereka anggap kitab utama termasuk Kutubus Sittah (6 Kitab utama hadits) yang terdiri dari 4 kitab Sunan (sunan Abu Dawud, Sunan Tarmidzi, Sunan Nasai, Sunan Ibnu Majah) dan 2 kitab Sahih (Sahih Buhari dan Muslim). Dalam ranah fiqih mereka diajarkan buku buku seperti Mabadi', Fathul Qorib, Fathul Muin dan al Minhaj. Buku buku tersebut ditambah penafsiran dari beberapa Amir dan ustadz membawa pemahaman untuk mencegah COVID-19 (UB, 2021).

Menurut salah satu pemimpin utama dari pesantren ini, hal penting yang perlu dilakukan untuk menghadapi Virus Corona adalah percaya atau yakin kepada Allah SWT, hanya Allah SWT lah yang dapat membawa keberuntungan atau kemalangan dari manusia. Apapun selain Allah SWT adalah makhluk. Nabi Muhammad Swt bersabda "tidak ada penyakit yang bisa dengan sendirinya menular, "la adwa". Konsep ini adalah nilainilai penting yang diajarkan di pesantren serta kepada jamaah lainnya. Selain itu juga menekankan kepada semua orang bahwa "la Ilaha Illallah" kurang kuat tanpa melibatkan kepercayaan pada "Muhammad Rasulullah". Ini berarti bahwa menerapkan keyakinan kepada Allah SWT harus didasarkan pada nasihat dan praktek praktek yang telah dicontohkan oleh Nabi Muhammad Saw (UU, 2021).

Menurut UB dalam menghadapi wabah, Nabi Muhammad Saw pernah bersabda ketika terjadi wabah kusta "Firra minal majdzum firaaraka minal asad", yang artinya hindarilah penderita kusta seperti halnya kamu lari dari Singa. Hadis ini dapat dijadikan rujukan, namun juga mempertimbangkan " $l a$ $a d w a$ " yang berarti tidak ada penyakit yang menular dengan sendirinya yang juga merefleksikan konsep "la Ilaha Illallah". Menurutnya langkah atau ikhtiar untuk menghindari kerumunan orang. Apa yang dikatakan oleh UB ini menggambarkan sikap Jamaah Tabligh yang plural dan juga bermain artikulasi dalam menghadapi suatu persoalan yang kontradiktif (UB, 2021).

Mereka cukup fleksibel dalam menyikapi penyakit COVID-19, di satu sisi mereka merujuk pada hadits tentang tidak ada penyakit menular, di sisi lain mereka juga tidak menafikkan usaha ikhtiar dengan pergi ke dokter dan berobat juga menghindari orang terkena penyakit tertentu, seperti halnya dalam hadits tentang menghindari orang berpenyakit kusta.

Pemikiran bisa saja berubah atau paradoks, namun perilaku yang ditampakkan terkadang bisa dijadikan rujukan tentang pendapat mana yang dominan. Hal ini karena memang jika melihat aktifitas di Masjid Al Burhan, sepertinya Jamaah Tabligh tidak terlalu khawatir tertularnya penyakit di antara mereka. Mereka tetap menyelenggarakan daurah dan taklim dalam jumlah 50 orang lebih. Sebagian besar dari mereka tidak memakai masker.

Kemungkinan besar yang menjadi dasar dari perilaku adalah, kepercayaan bahwa mereka sehat karena telah melakukan semaksimal mungkin contoh-contoh yang diberikan Rasulullah dalam kehidupan sehariharinya. Sehingga mereka yakin bahwa mereka akan kuat dalam menghadapi penyakit, jika memang mereka sakit atau meninggal itu semua karena kehendak Allah SWT. 
Penyebaran COVID-19 telah memantik perhatian dari para tokoh tokoh Islam, para ulama, Kiai, dan para ustadz untuk dapat memberikan pernyataan-pernyataannya. COVID-19 dalam pandangan UU adalah salah satu makhluk-makhluk Allah SWT dan menekankan bahwa semua muslim harus percaya bahwa semua penyakit, termasuk COVID-19, tidak akan menyerang seseorang tanpa izin Allah SWT (UU, 2021). UB menambahkan, namun seseorang harus berupaya untuk mencegah, menyembuhkan dan mengilangkan virus. Mengenai pernyataan pernyataan tentang COVID-19 dari beberapa anggota Jama ah yang lain, UB mengutip pernyataan tenar Arab "Kalimattu haqqin urida bihi al bathil", pernyataannya benar dengan maksud yang salah" terkait dengan COVID-19. Intinya, Allah SWT adalah satu satunya yang harus ditakuti, namun kehati-hatian terhadap penyakit atau wabah adalah kewajiban. UB mengaku tidak ada jamaah dari Al Burhan yang mengikuti kongress akbar di Gowa, tidak juga Jamaah yang berasal dari Gowa mengunjungi $\mathrm{Al}$ Burhan (UB, 2021).

Terkait banyak statemen tentang dengan COVID-19 dari beberapa Jamaah Tabligh yang kontraproduktif terhadap upaya pemerintah, UB mengatakan bahwa, Jamaah Tabligh memang bervariasi. Mereka berasal dari latar belakang yang berbeda-beda, tingkat keilmuannya juga berbeda-beda, ada yang berilmu tinggi ada juga yang dari kalangan tidak terdidik dan bahkan para mantan kriminal. Menurutnya, mereka yang baru bergabung dalam jama ah rata rata masih baru belajar Islam, dan memiliki semangat yang tinggi dalam beragama. Artinya jika pemahamannya baru sampai demikian maka perlu dimaklumi, karena apa yang dibicarakannya merupakan ekspresi semangatnya untuk belajar Islam dan menganggap peraturan peraturan-terkait COVID-19 menghambat aktivitas belajarnya.

Bagi anggota Jamaah Tabligh, Islam adalah agama yang sempurna. Islam mampu menurunkan keyakinan kepada Allah SWT dan Muhammad Rasulullah kepada praktek praktek yang sangat berguna untuk seluruh umat manusia di setiap sendi kehidupan. Artinya, hal-hal yang berkaitan dengan penyakit sudah dijelaskan dalam Islam. Islam memiliki mekanisme pertahanan terhadap segala macam penyakit, mulai dari cara makan, waktu tidur, hingga ibadah mahdhah jika dilakukan secara benar akan membuat manusia menjadi sehat.

Dalam konteks usaha preventif atau pencegahan terhadap COVID-19, UU menganjurkan untuk setiap muslim agar tidak membatalkan wudhu, "sering seringlah berwudhu walau tidak sedang akan shalat" dan berpuasa. Karena dengan wudhu, seperti halnya mencuci tangan, kegiatan ini mampu melarutkan segala macam kuman kuman, bakteri atau virus di badan dan puasa adalah upaya untuk memperkuat imun tubuh, karena dengan berpuasa membuat orang tidak mudah sakit. Selain itu selalu diiringi dengan dzikir dan mengikat Allah SWT, berdoa memohon kesehatan dan hidup mulia di dunia. Dzikir juga berarti ketertundukan makhluk terhadapNya, dan apapun yang terjadi sejatinya merupakan kehendak Allah SWT (UU, 2021).

\section{d. Respon Pesantren dalam Penerapan Protokol Kesehatan dan Kondisi Selama Pandemi}

Selanjutnya mengenai responnya terhadap pelaksanaan protokol kesehatan di lingkungan pesantren, baik Aulia Cendikia dan Ittifaqiyah menerapkan protokol kesehatan yang cukup ketat. Meski begitu, di Aulia Cendikia sempat terjadi kasus keterjangkitan yang kasusnya terjadi setelah aktifitas belajar mengajar di pesantren diliburkan. Keduanya juga sempat meliburkan santri pada masa awal pandemi di tahun 2020, namun menurut keterangan pengelola ittifaqiah tidak terjadi kasus terjangkit COVID-19 di antara para santri. Sementara Al Burhan tidak pernah meliburkan siswanya terkait dengan status pandemi. Protokol kesehatan yang terlihat pada spanduk dan banner nampaknya hanyalah lip service saja. Meski begitu, di pesantren ini tidak pernah terjadi kasus tertularnya virus COVID-19. Dari sini dapat dilihat bahwa tingkat kepatuhan akan kebijakan pemerintah dipengaruhi oleh afiliasi gerakan keagamaannya.

\begin{tabular}{ccc}
\hline Nama & Jumlah & $\begin{array}{c}\text { Kasus } \\
\text { Keterjangkitan }\end{array}$ \\
\hline Aulia & 1350 & $\begin{array}{c}25 \text { Santri } \\
7 \text { Ustadz }\end{array}$ \\
Cendikia & & 0 \\
\hline Ittifaqiyah & 7765 & 0 \\
\hline
\end{tabular}




\begin{tabular}{lll}
\hline Al Burhan 100 & 0 \\
\hline
\end{tabular}

\section{Tabel 1. Data Kasus COVID-19}

Terkait ketahanan pesantren dalam menghadapi situasi sulit, terbukti bahwa semua pesantren yang diteliti mampu bertahan ditengah pandemi. pesantren memiliki mekanisme dalam mempertahankan diri dari berbagai macam situasi yang cukup sulit di Indonesia. Memang, tidak dapat dipungkiri, bahwa respon pesantren Al Burhan terhadap COVID-19 cenderung kontraproduktif terhadap upaya pencegahan penularan pandemi, tidak seperti Ittifaqiah dan Aulia Cendikia, namun nyatanya pesantren ini memiliki caranya sendiri agar para santri atau warga pondok lainnya tetap sehat. Di samping itu, pesantren sebenarnya mampu memberikan alternatif di tengah kondisi sosial ekonomi yang sulit. Pesantren justru tidak terpengaruh dengan kondisi perekonomian nasional yang buruk, secara finansial pesantren tetaplah sehat. Justru kehadiran pesantren ternyata dapat meringankan beban para orang tua yang sedang dalam masa kesulitan ekonomi.

Terakhir terkait dengan kesulitan yang dihadapi pesantren dengan aturan pemerintah adalah pada proses transfer pengetahuan kepada santri jika dilakukan pembelajaran secara online. Ilmu-ilmu agama yang menjadi persoalan serius. Karena ilmu agama Islam secara tradisinya memang mengandalkan peran guru atau kiai dan suasana yang kondusif untuk belajar, dan sistem asrama atau ma'had menjadi tidak tergantikan untuk ini. Sedangakan untuk ilmu-ilmu pengetahuan umum sebenarnya juga memiliki kendala yang sama, namun di luar masih banyak lembaga pendidikan atau les yang dapat menjembatani hal itu. Sehingga dari temuantemuan ini jika nantionya kembali harus ada kebijakan pembatasan pergerakan masyarakat, pesantren tidak perlu memulangkan para santri mukimnya dan tetap menerapkan protokol kesehatan dan karantina wilayah pesantren yang baik.

\section{Kesimpulan}

Mengenai eksistensi COVID-19 dari wawancara yang didapatkan dari para pengelola pesantren, dapat diketahui ada tiga pemahaman pengelola pesantren di mana sebagian tidak mempercayai keberadaan COVID-19. mereka menganggap bahwa tidak ada penyakit yang baru, hal ini karena gejala gejala yang ada pada COVID-19 seperti halnya gejala dari penyakit-penyakit yang sudah ada. Selain itu, ada pula yang beranggapan bahwa tidak ada penyakit yang menular. Namun sebagian besar pengelola pesantren yang percaya bahwa COVID-19 itu ada dan harus diwaspadai.

Meskipun memiliki respon teologis yang berbeda namun dalam penerapan protokol kesehatan di lingkungan pesantren selama Pandemi terdapat dua hal. Pertama, pesantren menerapkan aturan dalam bentuk SOP pencegahan virus secara ketat, ini dilakukan oleh Pesantren Aulia Cendikia dan Ittifaqiyah. Sementara Al Burhan cenderung menerapkan secara longgar. Dari sini dapat disimpulkan bahwa besar dan kecilnya pesantren dan paham keagamaan yang dianutnya menentukan bagaimana penerapan protokol kesehatan di lingkungan pesantren.

\section{Daftar Pustaka}

Arikunto, S. (1992). Prosedur Penelitian: Suata Pendekatan Praktek. Jakarta: Rineka Cipta.

Arnani, M. (2020, Maret 12). Wabah Virus Corona, Terdeteksi pada Desember 2019 Hingga Jadi Pandemi Global. Diambil 25 Desember 2021, dari KOMPAS.com website: https://www.kompas.com/tren/read/2 020/03/12/113008565/timelinewabah-virus-corona-terdeteksi-padadesember-2019-hingga-jadi

Arrobi, M. Z., \& Nadzifah, A. (2020). Otoritas Agama di Era Korona: Dari Fragmentasi Ke Konvergensi? MAARIF, 15(1), 197-215. https://doi.org/10.47651/mrf.v15i1.8 5

Aula, S. K. N. (2020). Peran Tokoh Agama Dalam Memutus Rantai Pandemi COVID-19 di Media Online Indonesia. Living Islam: Journal of Islamic Discourses, 3(1), 125-148. https://doi.org/10.14421/lijid.v3i1.22 24

BK. (2021). Wawancara.

Darmawan, D., Miharja, D., Waluyajati, R. S. R., \& Isnaeniah, E. (2020). Sikap 
Keberagamaan Masyarakat Menghadapi Wabah COVID-19. Religious: Jurnal Studi AgamaAgama Dan Lintas Budaya, 4(2), 115-124.

https://doi.org/10.15575/rjsalb.v4i2.8 596

Dhofier, Z. (1980). The Pesantren Tradition: A Study of the Role of the Kyai in the Maintenance of the Traditional Ideology of Islam in Java. Monograph Series Press. https://doi.org/10.25911/5d74e363a6 ded

FT. (2021). Wawancara.

Hadi, A. C. (2020). Dinamika Agama Hingga Norma Baru Masyarakat di Tengah Pandemik COVID-19 (Studi Kasus Masyarakat Desa Ploso Ngawi). Religi: Jurnal Studi Agama-agama, 16 , 188. https://doi.org/10.14421/rejusta.2020 .1602-04

HZ. (2021). Wawancara.

Kahfi, S., \& Kasanova, R. (2020). Manajemen Pondok Pesantren di Masa Pandemi COVID-19 (Studi Pondok Pesantren Mambaul Ulum Kedungadem Bojonegoro). Pendekar: Jurnal Pendidikan Berkarakter, 3(1), 26-30. https://doi.org/10.31764/pendekar.v3 i1.2827

Kemdikbud. (2020, Juni 15). Panduan Penyelenggaraan Pembelajaran pada Tahun Ajaran dan Tahun Akademik Baru di Masa Covid-19. Diambil 25 Desember 2021, dari Kementerian Pendidikan, Kebudayaan, Riset, dan Teknologi website: https://www.kemdikbud.go.id/main/b $\log / 2020 / 06 /$ panduan-

penyelenggaraan-pembelajaran-padatahun-ajaran-dan-tahun-akademikbaru-di-masa-covid19

Kemenag, L. (2020). Survei Pengetahuan, Sikap dan Tindakan Umat Beragama Menghadapi COVID-19Penelusuran Google. Diambil 24 Desember 2021, dari https://www.google.com/search?q=S urvei+Pengetahuan $\% 2 \mathrm{C}+$ Sikap+dan
+Tindakan+Umat+Beragama+Meng hadapi+COVID-19

Kuswana, D., Qomaruzzaman, B., \& Mahatma, M. (2020). Agama dan Wabah: Tanggapan Ulama Jawa Barat atas Covid-19 tahun 2020. UIN Sunan Gunung Djati Bandung. Diambil dari http://digilib.uinsgd.ac.id/30780/

Mushodiq, M. A., \& Imron, A. (2020). Peran Majelis Ulama Indonesia Dalam Mitigasi Pandemi Covid-19 (Tinjauan Tindakan Sosial dan Dominasi Kekuasaan Max Weber). SALAM: Jurnal Sosial Dan Budaya Syar-i, 7(5), 455-472. https://doi.org/10.15408/sjsbs.v7i5.1 5315

NA. (2021). Wawancara.

NF. (2021). Wawancara.

Saebani, B. A. (2008). Metodologi Penelitian. Bandung: Pustaka Setia.

Sastry, S., \& Basu, A. (2020). How to Have (Critical) Method in a Pandemic: Outlining a Culture-Centered Approach to Health Discourse Analysis. Frontiers in Communication, $5, \quad 81$. https://doi.org/10.3389/fcomm.2020. 585954

UA. (2021). Wawancara.

UB. (2021). Wawancara.

UK. (2021). Wawancara.

UN. (2021). Wawancara.

US. (2021). Wawancara.

UT. (2021). Wawancara.

UU. (2021). Wawancara.

Zakaria, F. (2021, September 20). Respons Pesantren Atas Pandemi (Studi Kasus Pengambilan Keputusan Komunikasi Organisasi Terkait Penanganan Pandemi Covid-19 di Pesantren Pertanian Darul Fallah, Bogor). Diambil 24 Desember 2021, dari http://lipi.go.id/publikasi/ResponsPesantren-Atas-Pandemi-StudiKasus-Pengambilan-KeputusanKomunikasi-Organisasi-TerkaitPenanganan-Pandemi-Covid-19-diPesantren-Pertanian-Darul-FallahBogor/41631 